\title{
In vivo Anticancer Activity on Ehrlich Ascites Carcinoma (EAC) Cells and in vitro Antimicrobial Activity of Psidium guajava Bark Extracts
}

\author{
Md. Jakir Hossain ${ }^{1}$, Shashwata Biswas ${ }^{2}$, Mohammad Shahriar ${ }^{3}$, Sohidul Islam ${ }^{1}$ and Chowdhury Rafiqul Ahsan²* \\ ${ }^{I}$ Department of Biochemistry and Microbiology, North South University, Dhaka 1229, Bangladesh, ${ }^{2}$ Department of Microbiology, University of Dhaka, Dhaka \\ 1000, Bangladesh, ${ }^{3}$ Department of Pharmacy, University of Asia Pacific, Dhaka 1215, Bangladesh.
}

\begin{abstract}
This study was performed to evaluate the in vivo anticancer activity against ehrlich ascites carcinoma (EAC) cells and in vitro antimicrobial activity of Psidium guajava bark extracts. By soxhlet apparatus, the P. guajava bark extracts were obtained using four solvents (n-hexane, petroleum benzene, chloroform, and methanol) according to their increasing solubility. In case of in vivo anticancer activity of the sample extracts, mice were seeded with approximately $1 \times 10^{5}$ ehrlich ascites carcinoma (EAC) cells. After seven days of consecutive treatment, the negative and positive control groups ( $\mathrm{n}=8$ each group) showed an average $\mathrm{EAC}$ cell count of $2.4 \times 10^{8}$ and $1.8 \times 10^{8}$ respectively, and the experimental groups showed the cell count of $2.2 \times 10^{8}, 2.1 \times 10^{8}, 1.9 \times 10^{8}$, and $1.41 \times 10^{8}$ when mice received $\mathrm{h}$ hexane, petroleum benzene, chloroform, and methanol extract respectively. Experimental group that received methanol extract showed percent increase of life span (\% ILS) of 33.3 when compared with the negative control. However, treatment in a cyclic manner of the mice showed \% ILS of $\mathbf{5 2 . 1 5}$ for experimental group when compared negative control. In antimicrobial activity experiment, an intermediate zone of sensitivity of the crude methanol extract was found against Escherichia coli, Shigella flexneri, and Staphylococcus aureus when compared with amoxicillin. All these results indicated the anticancer activity and antimicrobial activity of the methanol extract of P. guajava barks on different experimental models.
\end{abstract}

Key words: Psidium guajava, anticancer activity, antimicrobial activity.

\section{Introduction}

Medicinal plants contain alluring ingredients those are significantly active against many diseases like cancer $^{1-3}$. Psidium guajava is a small medicinal tree that is found all over the world. It is popularly known as guava under the family Myrtaceae and has been used traditionally as a medicinal plant throughout the world ${ }^{4,5}$. In rural areas of Bangladesh, the fruits, leaf, bark, and roots of this plant are prescribed by the village quack to treat antispasmodic, anti-inflammatory, cough sedative, anti-diarrheic, hypertension, obesity, and diabetes mellitus ${ }^{6-10}$. However, there are no scientific data on the biological activity of this plant or its compounds. In this study, we determined the in vivo anticancer activity against EAC cells and antimicrobial activity of P. guajava bark extracts.

\section{Materials and methods}

\section{Collection and processing of plant samples}

The barks of P. guajava were collected from Gazipur District, Bangladesh and the plant sample was submitted to the National Herbarium of Bangladesh, Mirpur-1, Dhaka for its identification. Barks were sun dried to remove the moisture and ground into coarse powder. Thirty gram of grinded P. guajava bark samples were extracted in a soxhlet apparatus and then crude extracts were obtained using four different solvents n-hexane, petroleum benzene, methanol, and chloroform, according to their increasing solubility. The extracted samples were stored at $4^{\circ} \mathrm{C}$ for future use.

\section{Measurement of Anticancer Activity}

Swiss albino mice of 25-30 gm collected from ICDDR, B were used for this study. Approximately $1.1 \times 10^{5}$ ehrlich ascites carcinoma (EAC) cells were injected intraperitoneally into the mouse. The positive control, negative control, and experimental groups were divided into 3 subgroups in each. The subgroup 1 of the experimental group was further divided into 4 according to the name of the extract that was given to the mice (n-hexane, petroleum benzene, chloroform, and methanol).

In the positive control group, all mice received Bleomycin from a cumulative dose of $0.3 \mathrm{mg}$ per $\mathrm{kg}$ body weight per week. The negative control and the experimental group were received Tween 20 (used to dissolve the extracts) and sample extracts respectively with a same cumulative dose of $200 \mathrm{mg}$ per $\mathrm{kg}$ body weight per week in each group.

All mice under subgroup 1 of all three groups were subject to cell count on day 8. Mice under subgroup 2 of all three groups were observed for survival in terms of days after seven consecutive days of treatment. Mice belongs to subgroup 3 of all three groups (mice received Tween 20 for negative, bleomycin

*Corresponding author:

Dr. Chowdhury Rafiqul Ahsan, Department of Microbiology, University of Dhaka, Dhaka 1000, Bangladesh e-mail: crahsan@du.ac.bd 
for positive, and methanol extracts for experimental group respectively in a cyclic manner; a consecutive seven days treatment followed by five days interval and this cycle was repeated until the death of mouse in this subgroup) were monitored for survival in terms of days. The mean survival time (MST) and percentage increase in life span (\%ILS) were calculated using following equations ${ }^{11}$ :

Survival time (days) of each mouse in a group

Mean survival time $(\mathrm{MST})=$

Total number of mice

MST of treated group

Percent increase in life span (\%ILS) $=\left(-\frac{1}{-1}\right) \times 100$ MST of control group

Antimicrobial activity

Disc diffusion method was applied to evaluate the effectiveness of sample extracts against Gram positive and Gram negative bacteria $^{12}$. To standardize the inoculum density, 0.5 McFarland standard was used. In this experiment, barks extract with the concentration of $500 \mu \mathrm{g} / 10 \mu \mathrm{l}$ in each disk was used to observe the antimicrobial activity. Two Gram negative bacteria E. coli (ATCC-25922) and Shigella flexneri (ATCC-12023) and one Gram positive bacteria Staphylococcus aureus (ATCC-25923) were taken and the results were compared with that of an antibiotic (amoxicillin), which served as positive control. Respective solvents were served as negative control.

\section{Results and Discussion}

Evaluation of in vivo anticancer activity

EAC cells count after treatment (subgroup 1)

Mice in all subgroup 1 were used to observe the number of EAC cells reduced after the treatment from day 1 to day 7. After seven days of treatment, EAC cells were counted on day 8. Subgroup 1 of negative and positive control group showed an average EAC cell count of $2.4 \times 10^{8}$ and $1.8 \times 10^{8}$ respectively. The experimental group showed a cell count of $2.2 \times 10^{8}$ when mice received hhexane whereas, $2.1 \times 10^{8}, 1.9 \times 10^{8}$, and $1.41 \times 10^{8}$ when mice received petroleum benzene, chloroform, methanol extract respectively. The methanol extract showed the maximum EAC cells reducing activity (Table 1). Therefore, further experiment was performed using methanol extract to evaluate in vivo anticancer activity.

Percent increased in life span (\% ILS) (subgroup 2)

The positive control, negative control, and experimental group were observed for their survival in days up to the death of all mice. The methanol extract showed the highest EAC cells reducing capacity in the experimental group and therefore, \%ILS was observed only the mice those were received methanol extract. The mean survival time (MST) of subgroup 2 of negative and positive control groups were 27.8 and 32 days respectively. Where the subgroup 2 of the experimental group (received only methanol extract) was 34 days. Therefore, percent increased in life span (\% ILS) was calculated against negative control and \% ILS of subgroup 2 of positive and experimental groups were found to be 18.7 and 22.30 respectively (Figure 1 ).

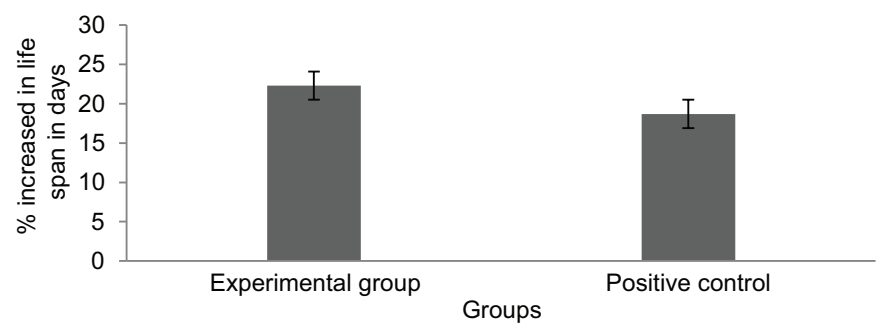

Figure 1. Percent increased in life span (\% ILS) of the experimental and control groups after seven consecutive days of treatment.

Percent increased in life span (\% ILS) after cyclic treatments (subgroup 3)

In subgroup 3 of all three groups, treatment with component (Tween 20 for negative, bleomycin for positive, and methanol extracts for experimental group respectively) was carried out in a cyclic manner (consecutive seven days treatment followed by five days interval and this cycle was repeated until the death of mouse in this subgroup). The mean survival time (MST) of subgroup 3 of negative and positive control groups were 27.8 and 37.5 days respectively and the experimental group was 42.3 days. Percent increased in life span (\% ILS) was calculated against negative control and the \% ILS of the positive control and experimental group were found to be 35.79 and 52.15 respectively (Figure 2). This study showed the rate of life span was higher when mice were given the sample extract in a cyclic manner.

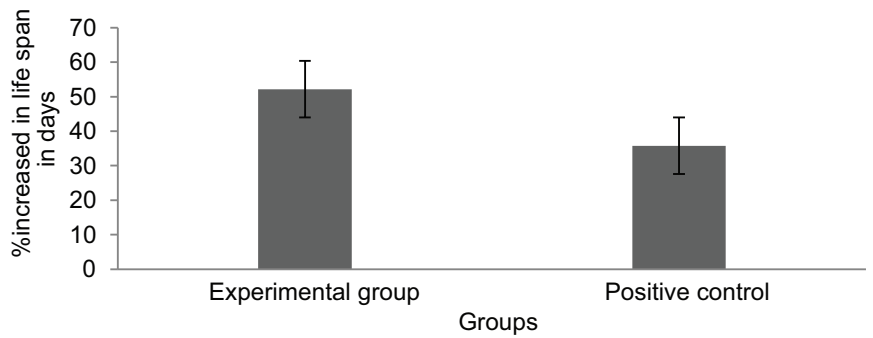

Figure 2. Percent increased in life span (\% ILS) of subgroup 3 of positive control and experimental group.

Table 1. Comparison of the ehrlich ascites carcinoma cells counts among the groups.

\begin{tabular}{cccccr}
\hline Cell count & \multicolumn{5}{c}{ Groups } \\
\cline { 2 - 6 } & Negative control & Positive & \multicolumn{4}{c}{ Experimental group } \\
\cline { 3 - 6 } & control & n-hexane & Petroleum benzene & Chloroform & Methanol \\
\hline $2.4 \times 10^{8}$ & $1.8 \times 10^{8}$ & $2.2 \times 10^{8}$ & $2.1 \times 10^{8}$ & $1.9 \times 10^{8}$ & $1.41 \times 10^{8}$ \\
\hline
\end{tabular}




\section{Evaluation of the antimicrobial activity}

In this antimicrobial activity assay, the experimental samples showed bacterial growth inhibition against two Gram negative bacteria (E.coli and S. flexneri) and one of Gram positive bacteria (S. aureus). Zone of inhibition of the methanol extract was found (12 mm for E.coli, $11 \mathrm{~mm}$ for $S$. flexneri and $15.5 \mathrm{~mm}$ for $S$. aureus) in comparison to amoxicillin (18 $\mathrm{mm}$ for all species) (Table 2). According to FDA standard $<13 \mathrm{~mm}$ in diameter is resistant and 14-17 $\mathrm{mm}$ is intermediate whereas, $>18 \mathrm{~mm}$ of zone of inhibition is sensitive for amoxicillin ${ }^{13}$. So, the methanol extract showed least antimicrobial activity against E.coli, S. flexneri, and $S$. aureus.

Table 2. Evaluation of the antimicrobial activity of sample extracts.

\begin{tabular}{lccccc}
\hline $\begin{array}{l}\text { Name of the } \\
\text { organisms }\end{array}$ & \multicolumn{5}{c}{ Zone of inhibition in diameter (mm) } \\
\cline { 2 - 6 } & n-hexane & $\begin{array}{c}\text { Petroleum } \\
\text { benzene }\end{array}$ & Chloroform & Methanol & Amoxicillin \\
\hline E. coli & 0 & 0 & 0 & 12 & 18 \\
S. flexneri & 0 & 0 & 0 & 11 & 18 \\
S. aureus & 0 & 0 & 0 & 15.5 & 18 \\
\hline
\end{tabular}

\section{Conclusion}

From above result, it can be inferred that methanol extract of sample bark has potent in vivo anticancer effect to some extand in terms of the capacity of the extract to reduce intraperitoneal cancer cell count and increased survival of the experimental animal and antimicrobial capacity. Further study should be included for the isolation of pharmacologically active ingredients from the methanol extract of the bark of P. guajava and evaluation of each active ingredient.

\section{References}

1. Edward, A., 2001. Pathogenesis Justiciaadhatoda (ed) New. Old and Forgotten remedies, pp.210-220.
2. Shinwari, M.I., and Khan, M.A., 1998. Indigenous use of medicinal trees and shrubs of Margalla Hills National Park, Islamabad. Pakistan Journal of Forestry, 48(14), pp.63-90.

3. Islam, E., Islam, R., Rahman, A.A., Alam, A.K., Khondkar, P., Rashid, M. and Parvin, S., 2013. Estimation of total phenol and in vitro antioxidant activity of Albiziaprocera leaves. BMC research notes, 6(1), p.121.

4. Kaneria M, Chanda S. 2011. Phytochemical and Pharmacognostic Evaluation of Leaves of Psidium guajava L. (Myrtaceae). Pharmacog 23: $32-41$.

5. Haida KS, Baron A, Haida KS. 2011. Phenolic compounds and antioxidant activity of two varieties of guava and rue. Rev Bras Ciênc Saúde 28: 1119.

6. Ryu NH, Park KR, Kim SM, Yun HM, Nam D, et al. 2012. A Hexane Fraction of Guava Leaves (Psidium guajava L.) Induces Anticancer Activity by Suppressing AKT/Mammalian Target of Rapamycin/ Ribosomal p70 S6 Kinase in Human Prostate Cancer Cells. J Med Food 15: $231-241$

7. Pelegrini PB, Murad AM, Silva LP, Dos Santos RC, Costa FT, et al. 2008. Identification of a novel storage glycine-rich peptide from guava (Psidium guajava) seeds with activity against Gram-negative bacteria. Peptides 29: 1271-1279.

8. Metwally AM, Omar AA, Harraz FM, El Sohafy SM. 2010. Phytochemical investigation and antimicrobial activity of Psidium guajava $\mathrm{L}$ leaves. Pharmacogn Mag 6: 212-218.

9. Huang CS, Yin MC, Chiu, LC. 2011. Antihyperglycemic and antioxidative potential of Psidium guajava fruit in streptozotocin-induced diabetic rats. Food Chem Toxicol 49: 2189-2195.

10. Bontempo P, Doto A, Miceli M, Mita L, Benedetti R, et al. 2012. Psidium guajava L. anti-neoplastic effects: induction of apoptosis and cell differentiation. Cell Prolif 45: 22-31.

11. Biswas, S., Shahriar, M., Khanam, J.A. and Ahsan, C.R. 2016. Investigation of Antioxidant, In-vitro Cytotoxic, and In-vivo Antitumor Effects of Leaf Extracts of AnnonaReticulata. Bangladesh Journal of Microbiology, 29(2), pp.70-74.

12. Rabah, B., Lograda, T., Ramdani, M., Chalard, P. and Feguiredo, G. 2013. Chemical composition and antibacterial activity of essential oil of ziziphorahispanica 1. Global Journal of Research on Medicinal Plants \& Indigenous Medicine, 2(2), p.73.

13. Boyle, V.J., Fancher, M.E. and Ross, R.W. 1973. Rapid, modified KirbyBauer susceptibility test with single, high-concentration antimicrobial disks. Antimicrobial agents and chemotherapy, 3(3), pp.418-424. 